\title{
A taxonomic reassessment of the genus Balsamia from China
}

\author{
Yu-Yan Xu', Xiang-Yuan Yan', Ting Li', Li Fan' \\ I College of Life Science, Capital Normal University, Xisanhuanbeilu 105, Haidian, Beijing 100048, China \\ Corresponding author: Li Fan (fanli@mail.cnu.edu.cn)
}

Academic editor: T. Lumbsch | Received 12 January 2020 | Accepted 13 May 2020 | Published 4 June 2020

Citation: Xu Y-Y, Yan X-Y, Li T, Fan L (2020) A taxonomic reassessment of the genus Balsamia from China. MycoKeys 67: 81-94. https://doi.org/10.3897/mycokeys.67.50068

\begin{abstract}
Molecular analysis of the genus Balsamia was conducted with ITS and 28S sequences available, including newly gained sequences from Chinese specimens. Combined with the morphological examinations, a new hypogeous species, Balsamia lishanensis was described and illustrated from North China, which is morphologically characterized by reddish brown ascomata covered with fine warts, the whitish gleba with numerous small chambers, 3-5 layers peridium with reddish brown polygonal cells and the smooth and regular ellipsoid ascospores with one large oil drop. Two species previously described as Barssia were transferred to Balsamia. Balsamia platyspora was confirmed to be in existence in China based on newly collected specimen. A key to the Chinese Balsamia species was provided.
\end{abstract}

\section{Keywords}

Ascomycota, Helvellaceae, Hypogeous fungi, phylogeny, taxonomy

\section{Introduction}

The genus Balsamia Vittad. (Helvellaceae, Pezizales), with B. vulgaris Vittad. as the type species, was established in the early $19^{\text {th }}$ century (Vittadini 1831), usually forming ectomycorrhizae with both broad leaf and conifer trees (Southworth et al. 2018; Hansen et al. 2019). Geographically, Balsamia species are widely distributed across Europe, North America, North Africa and Asia in the temperate regions of the northern hemisphere (Liu and Tao1990; Pegler et al.1993; Southworth et al. 2018; Hansen et al. 2019). Until now, nine Balsamia species have been reported from Europe (Vittadini

Copyright Yu-Yan Xu et al. This is an open access article distributed under the terms of the Creative Commons Attribution License (CC BY 4.0), which permits unrestricted use, distribution, and reproduction in any medium, provided the original author and source are credited. 
1831; Tulasne and Tulasne 1843; Berkely 1844; Tulasne and Tulasne 1851; Schulzer 1870; Petitberghien 1966; Ławrynowicz and Skirgiełło 1984; Kaounas et al. 2015; Hansen et al. 2019), twelve from North America (Southworth et al. 2018), and one from North Africa (Crous et al. 2014; Hansen et al. 2019) In China, this genus is poorly understood as only one species Balsamia platyspora Berk. is reported, based on morphological evidence (Liu and Tao 1990).

Recently, two new species of the genus Barssia have been described from China (Xu et al. 2018), their taxonomic position, however, needs to be reassessed because Hansen et al. (2019) synonymized Barssia under Balsamia based on their phylogenetic analysis from three loci $(28 S, R P B 2, E F-1 a)$ and morphological studies. More recently, an un-described Balsamia species is recognized when we check the specimens newly collected from north China. In this paper, both the molecular analyses and morphological examinations are conducted for the Chinese samples,, and our aims are:1) to illustrate the position of Chinese Balsamia species based on ITS and 28S sequences newly obtained from Chinese Balsamia collections with distinct features in this study as well as recently published and used sequences ; 2 ) to give a detailed characterization of a new species based on morphological features and phylogenetic evidences.

\section{Materials and methods}

Morphological studies

Collections were obtained and photographed in the field from Shanxi regions in China, and they were dried and deposited in BJTC (Herbarium, Biology Department, Capital Normal University). One specimen was studied from HMAS (Herbarium Mycologicum Academiae Sinicae, Institute of Microbiology, Chinese Academy of Sciences). Macroscopic characters were recorded from fresh specimens. Microscopic characters were observed in thin sections of dry specimens mounted in 3\% $\mathrm{KOH}$, Melzer's reagent (Dring 1971) or $0.1 \%(\mathrm{w} / \mathrm{v})$ cotton blue in lactic acid. Thirty mature ascospores were measured, and the symbol Q is used to indicate length/width ratios of ascospores in side view.

\section{DNA extraction, PCR amplification and DNA sequencing}

Herbarium specimens were crushed by shaking for $30 \mathrm{~s}$ at $30 \mathrm{~Hz} 2-4$ times (Mixer Mill MM 301, Retsch, Haan, Germany) in a $1.5 \mathrm{ml}$ tube together with one $3 \mathrm{~mm}$ diam. tungsten carbide ball, and total genomic DNA was extracted using the modified CTAB method (Gardes and Bruns 1993). The internal transcribed spacer (ITS) region of nuclear ribosomal DNA (nrDNA) was amplified using primers ITS1f/ITS4 (White et al. 1990; Gardes and Bruns 1993). The $28 \mathrm{~S}$ large subunit nrDNA (nrLSU) region was amplified using primers LR0R/LR5 (Vilgalys and Hester 1990). PCRs were 
performed in a volume of $50 \mu \mathrm{l}$ consisted of $4 \mu \mathrm{l}$ of DNA template; $2 \mu \mathrm{l}$ of $(10 \mu \mathrm{M})$ per primer; $25 \mu \mathrm{l} 2 \times$ Master Mix (Tiangen Biotech Co., Beijing). The procedure for PCR reaction was: an initial denaturation at $94^{\circ} \mathrm{C}$ for $3 \mathrm{~min}$; followed by 35 cycles at $94{ }^{\circ} \mathrm{C}$ for $30 \mathrm{~s}, 55^{\circ} \mathrm{C}$ for $45 \mathrm{~s}, 72{ }^{\circ} \mathrm{C}$ for $1 \mathrm{~min}$; and a final extension at $72{ }^{\circ} \mathrm{C}$ for $10 \mathrm{~min}$. The PCR products were sent to Beijing Zhongkexilin Biotechnology Co. Ltd. (Beijing, China) for purifying, sequencing and editing. Validated sequences are stored in the NCBI database (http://www.ncbi.nlm.nih.gov/) under the accession numbers provided (Table1). The other sequences used in the molecular phylogenetic analysis were downloaded from the NCBI database (Suppl. material 1).

\section{Phylogenetic analyses}

Two datasets, ITS and 28S, were compiled to identify Balsamia species and investigate relationships among species. The taxa Tuber anniae and T. bellisporum were selected as outgroups. The ITS and 28S sequences were aligned using the MAFFT v.7.110 online program under default parameters (Katoh and Standley 2013), and manually adjusted to allow maximum sequence similarity in Se-Al version.2.03a. (Rambaut 2000). Ambiguously aligned regions and gaps in alignment were excluded by $\mathrm{Se}-\mathrm{Al}$ version.2.03a. (Rambaut 2000) before the phylogenetic analysis. Alignments were submitted to TreeBASE under accession number S25937. We conducted maximum likelihood (ML), most parsimonious (MP) and Bayesian inference (BI) analyses on the two datasets.

Maximum likelihood (ML) analysis of the dataset was carried out using RAxML 8.0.14 (Stamatakis 2014) and the GTRGAMMA substitution model with parameters unlinked. The ML bootstrap replicates (1000) were computed in RAxML using a rapid bootstrap analysis and search for the best-scoring ML tree. The ML trees were viewed with TreeView32 (Page 2001). Clades with bootstrap support (MLBS) $\geq 70 \%$ were considered as significant-supported (Hillis and Bull 1993).

A most parsimonious (MP) analysis was constructed with PAUP* 4.0b10. (Swofford 2002). The bootstrap values were generated using the following settings: 1000 replicate searches on all parsimoniously informative characters using 100 random sequence addition replications and TBR (tree-bisection reconnection) branch swapping

Table I. Information on newly generated DNA sequences used in this study.

\begin{tabular}{l|c|c|c|c}
\hline Fungal taxon & Specimen voucher & Locality & ITS & 28S \\
\hline Balsamia lishanensis & BJTC FAN587 & Shanxi, China & MT232721 & MT232903 \\
\cline { 2 - 4 } & BJTC FAN591 & Shanxi, China & MT232899 & MT232911 \\
\cline { 2 - 4 } & BJTC FAN676 & Shanxi, China & MT232907 & MT232902 \\
\cline { 2 - 5 } & BJTC FAN689 & Shanxi, China & MT232905 & MT232914 \\
\cline { 2 - 5 } & BJTC FAN697 & Shanxi, China & MT232908 & MT232912 \\
\cline { 2 - 5 } & BJTC FAN714 & Shanxi, China & MT232901 & MT232913 \\
\cline { 2 - 5 } & BJTC FAN1010 & Shanxi, China & MT232900 & MT232910 \\
\cline { 2 - 5 } & HMAS 97115 & Gansu, China & MT232904 & MT232909 \\
\hline Balsamia platyspora & BJTC FAN557 & Shanxi, China & MT232906 & MT3 \\
\hline
\end{tabular}


algorithms in PAUP*. Tree statistics (TL), consistency index (CI), retention index (RI) and homoplasy index (HI) were also calculated. Tree was viewed with TreeView32 (Page 2001). Clades with bootstrap support (MPBS) $\geq 70 \%$ were considered to be significant (Hillis and Bull 1993).

Bayesian inference (BI) analyses was performed with MrBayes v3.1.2 (Ronquist and Huelsenbeck 2003) based on the best substitution models determined by MrModeltest 2.3 (Nylander 2004), which were GTR $+\mathrm{I}+\mathrm{G}$ for the ITS dataset and SYM+I+G for the $28 \mathrm{~S}$ dataset. Two independent runs of four chains were conducted for 4000 000 for ITS and 2000000 for 28S datasets Markov Chain Monte Carlo generations using the default settings and sampled every 100 generations. The temperature value was lowered to 0.20 , burn-in was set to 0.25 , and the run was automatically stopped as soon as the average standard deviation of split frequencies reached below 0.01. A 50\% majority-rule consensus tree was constructed and visualized with TreeView32 (Page 2001). Clades with Bayesian posterior probability (BPP) $\geq 0.95$ were considered as significantly supported (Alfaro et al. 2003).

\section{Results}

\section{Phylogenetic analysis}

For ITS dataset, we comprehensively collected the ITS sequences of Balsamia and the fungi previously described as Barssia, and sequences that are high similarity to Balsamia. For $28 \mathrm{~S}$ dataset, we collected all sequences of Balsamia and the fungi previously described as Barssia, and representative sequence of other genera of Helvellaceae. Sequences of each locus were aligned and analyzed separately.

The 28S dataset contained 72 sequences ( 9 were newly gained in this study), and 4 from the outgroup Tuber anniae and T. bellisporum. The dataset had an aligned length of 886 characters, of which 578 were constant, 308 were variable, and 278 of these variable sites were informative. The maximum parsimony analysis resulted in one most parsimonious tree with a length (TL) of 842 steps, consistency index (CI) of 0.570 , retention index (RI) of 0.896 , homoplasy index (HI) of 0.430 . MP, ML and BI analyses yielded similar tree topologies, and only the tree inferred from the MP analysis is shown (Fig. 1). The $28 \mathrm{~S}$ sequences of Balsamia were grouped into a distinct clade with high supports (MPBS $=100 \%$, MLBS $=100 \%, \mathrm{BPP}=1.00)$. The Chinese materials were well clustered in the Balsamia clade (Fig. 1), including the sequences of the fungi previously described as Barrsia guozigouensis L. Fan \& Y.Y. Xu and Barssia luyashanensis L. Fan \& Y.Y. Xu (Xu et al. 2018). Three distinct branches with strong supports can be recognized from Chinese collections, respectively representing Balsamia guozigouensis, Balsamia luyashanensis, and a new species Balsamia lishanensis proposed in this study. In addition, the Chinese sequence from BJTC FAN557 grouped together with a reliably identified sequence (MK100252) of B. platyspora (Hansen et al. 2019) with strong support value (MPBS = $99 \%$, MLBS $=99 \%, \mathrm{BPP}=1.00)$, and they shared $99.83 \% 28 \mathrm{~S}$ sequences similarity, indicating the Chinese specimen BJTC FAN557 was B. platyspora. 


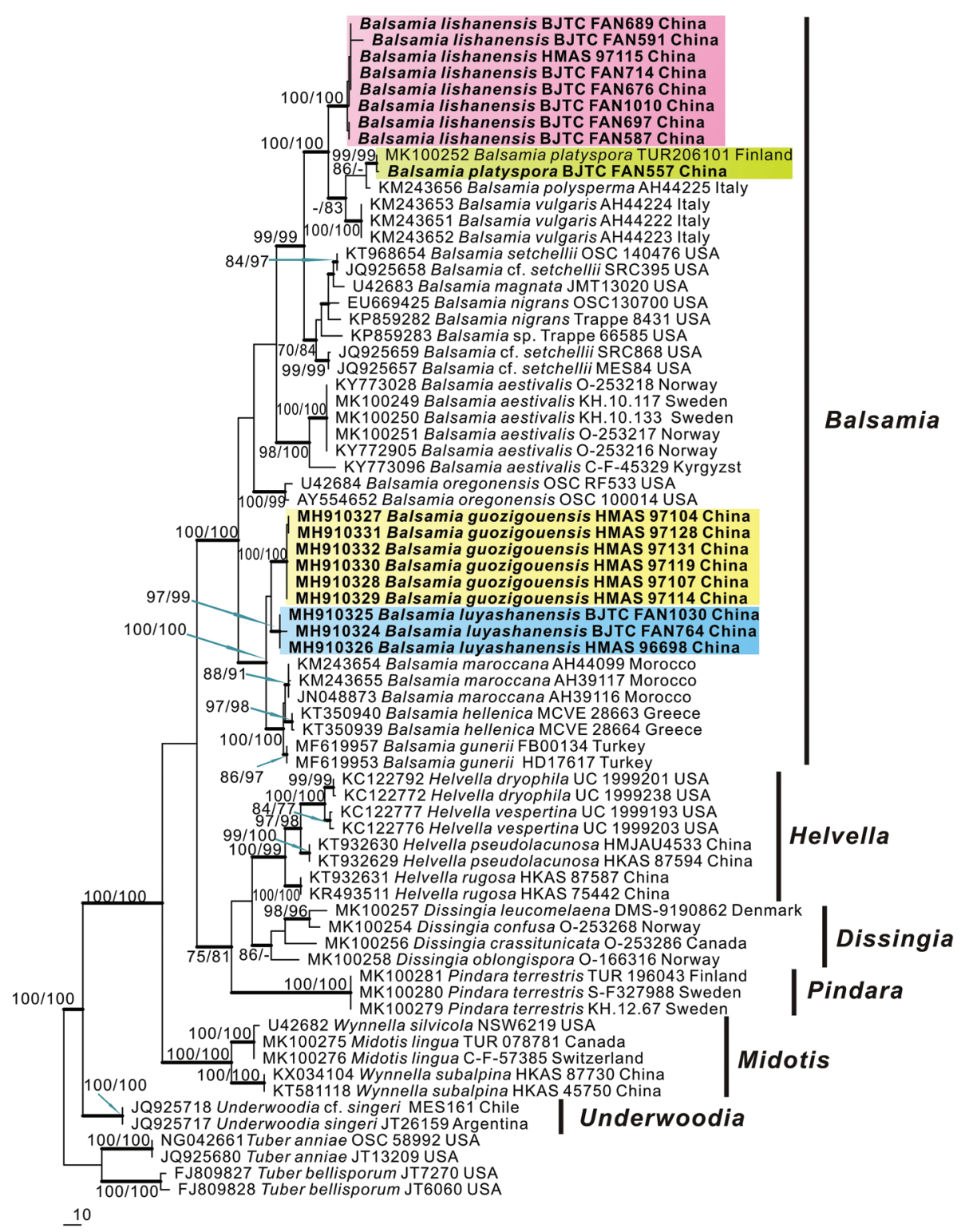

Figure I. Phylogenetic tree generated from a maximum parsimonious analysis based on $28 \mathrm{~S}$ sequences, showing the phylogenetic relationships of Helvellaceae. Tuber anniae and T. bellisporum are the outgroups. Maximum parsimonious bootstrap support values $(\geq 70 \%)$ and maximum likelihood bootstrap support values $(\geq 70 \%)$ are indicated above the nodes as MPBS/MLBS. Thick black branches received Bayesian posterior probabilities $(\mathrm{BPP}) \geq 0.95$. Novel sequences are printed in bold.

The ITS dataset contained 108 sequences ( 9 were newly gained in this study), and 4 from the outgroup T. anniae and T. bellisporum. The dataset had an aligned length of 1056 characters, of which 310 were constant, 745 were variable, and 622 
of these variable sites were informative. The maximum parsimony analysis resulted in one most parsimonious tree with a length (TL) of 2220 steps, consistency index (CI) of 0.580 , retention index (RI) of 0.900 , homoplasy index (HI) of 0.420. MP, ML and $\mathrm{BI}$ analyses yielded similar tree topologies, and only the tree inferred from the Bayesian analysis is shown (Fig. 2). The ITS sequences of Balsamia were grouped into a distinct clade with high supports (MPBS $=100 \%$, MLBS $=100 \%, \mathrm{BPP}=1.00)$, and the sequences from the Chinese collection unambiguously clustered in the Balsamia

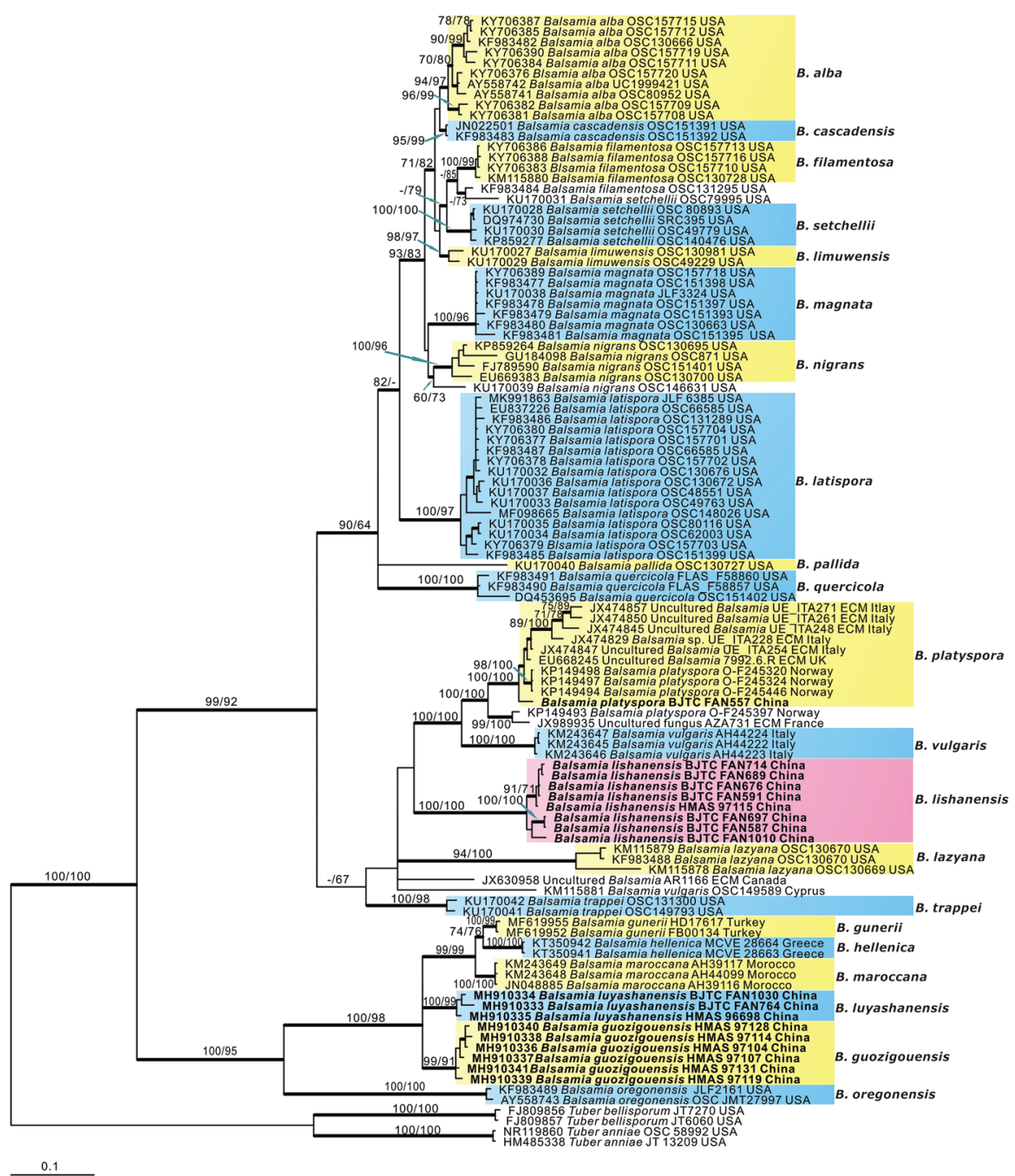

Figure 2. Phylogenetic tree generated from Bayesian analysis based on ITS sequences, showing the phylogenetic relationships of Balsamia. Tuber anniae and T. bellisporum are the outgroups. Maximum parsimonious bootstrap support values $(\geq 70 \%)$ and maximum likelihood bootstrap support values $(\geq 70 \%)$ are indicated above the nodes as MPBS/MLBS. Thick black branches received Bayesian posterior probabilities (BPP) $\geq 0.95$. Novel sequences are printed in bold. 
clade, including the sequences of the fungi previously described as Barrsia guozigouensis and Barssia luyashanensis (Xu et al. 2018) (Fig. 2). The sequences of all Chinese collections excepting specimen BJTC FAN557 were grouped into three independent clades with strong supports (Fig. 2), respectively representing Balsamia guozigouensis, Balsamia luyashanensis and a new species Balsamia lishanensis proposed in this study. The sequence of BJTC FAN557, which was identified as B. platyspora by morphology and 28 S phylogeny (Fig. 1) in this study, formed a strong support clade together with nine European sequences isolated from ascomata of Balsamia platyspora or ectomycorrhizal root tips of Balsamia. These ten samples showed high sequences similarity so the clade was considered as representing $B$. platyspora.

Based on the above phylogenetic analyses (Figs 1, 2), we concluded that Barrsia guozigouensis and Barssia luyashanensis should be transferred to Balsamia. The clade of $B$. lishanensis was a distinct species and represented a new species. The specimen BJTC FAN557 should be recognized as the European Balsamia platyspora.

\section{Taxonomy}

\section{Balsamia lishanensis L. Fan \& Y.Y. Xu, sp. nov.} MycoBank No: 834962

Figure 3

Etymology. lishanensis, Lishan Mountain, referring to the locality where the type specimen was collected.

Holotype. China. Shanxi Province, Yuanqu County, Lishan Mountain Shunwangping Scenic Area, alt. 2300 m, 17 October 2016, in soil under Pinus armandii Franch., M. Chen CM019 (BJTC FAN676).

Ascomata subglobose to irregularly subglobose, $3-14 \times 2-12 \mathrm{~mm}$ in fresh, reddish brown when fresh, usually with some superficial furrows, surface covered with verrucose or fine warts, warts obtuse or pointed, $270-400 \mu \mathrm{m}$ wide and 150-300 $\mu \mathrm{m}$ high. Odor light, mushroom flavor. Gleba solid, white to cream white, with numerous irregular canals and chambers of around $1 \mathrm{~mm}$ width. Peridium 150-350 $\mu \mathrm{m}$ thick, two-layered, outer layer pseudoparenchymatous, 90-190 $\mu \mathrm{m}$ thick, composed of 3-5 layers of reddish brown polygonal cells with 4-6 sides, cells $15-35 \times 10-27 \mu \mathrm{m}$, walls $4.0-8.0 \mu \mathrm{m}$ thick, the outermost cells reddish-brown, and gradually light-yellow to hyaline towards inner side; inner layer 60-150 $\mu \mathrm{m}$ thick, composed of interwoven hyphae, that is more or less parallel to the surface of peridium, hyphae hyaline, 2.5-6.0 $\mu \mathrm{m}$ wide. Paraphyses line the surface of chamber, arranged like a fence, $3-4 \times 50 \mu \mathrm{m}$, but disorganized in the mature ascomata, usually not well-defined. Asci 8-spored, hyaline, citriform or fusiform, $55-80 \times 27-38 \mu \mathrm{m}$ (not including stalk), inamyloid, with a slender-stalk of 13.5-35 $\times$ 5-10 $\mu \mathrm{m}$, spores irregularly arranged in ascus. Ascospores ellipsoid, smooth, hyaline, inamyloid, 20.6-25.6 × 12.9-15 $\mu \mathrm{m}$ (av. 23.5 × 14.0 $\mu \mathrm{m}), \mathrm{Q}(\mathrm{L} / \mathrm{I})=1.55-1.80(\mathrm{Qm}=$ 1.68) $(\mathrm{n}=30)$, usually containing one large oil drop and several small droplets. 


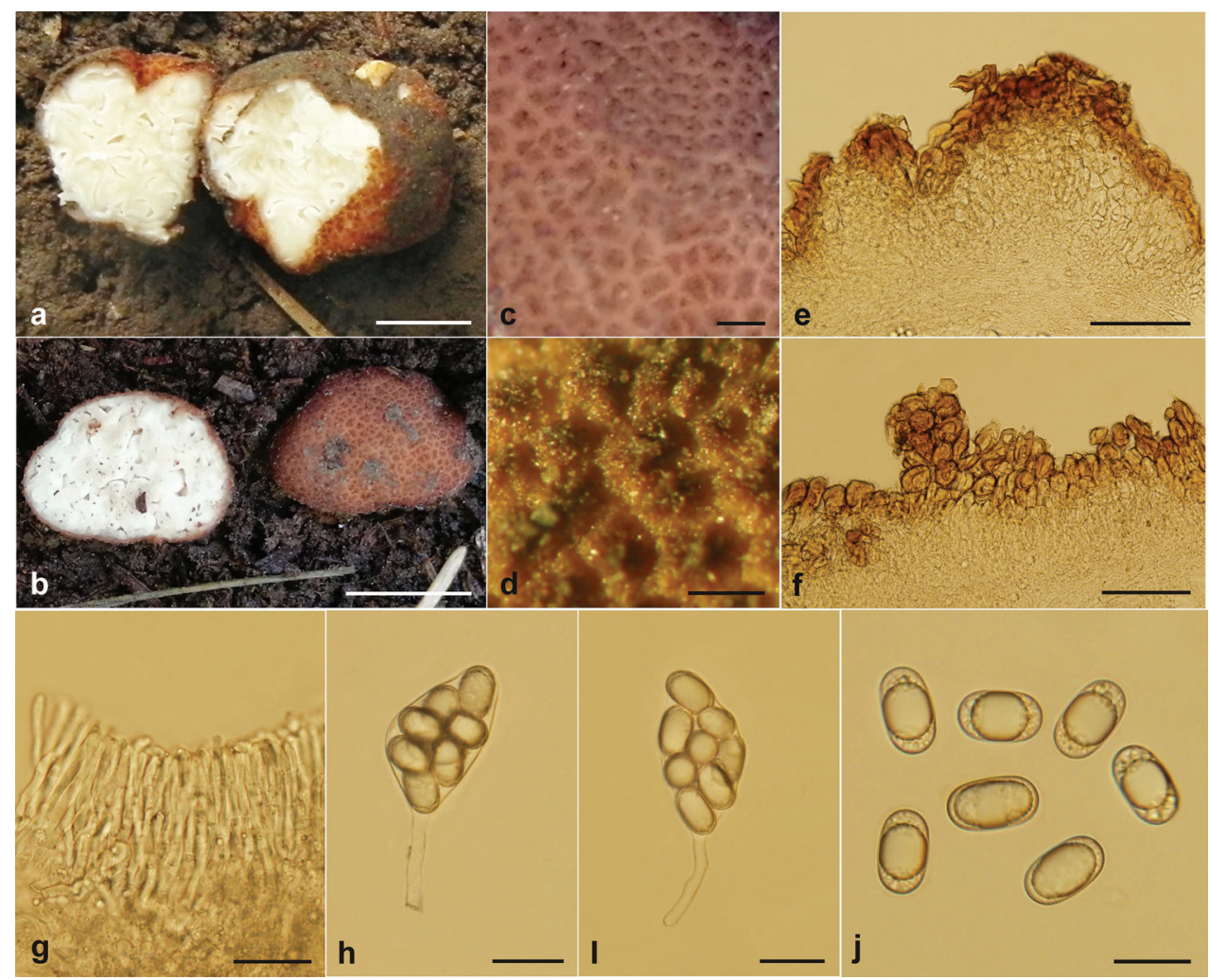

Figure 3. Balsamia lishanensis (BJTC FAN676, holotype) a, b ascomata c warts (when fresh) d warts (when dry) e, $\mathbf{f}$ peridium $\mathbf{g}$ paraphyses $\mathbf{h}, \mathbf{i}$ mature ascus $\mathbf{j}$ ascospores. Scale bars: $5 \mathrm{~mm}(\mathbf{a}, \mathbf{b}) ; 500 \mu \mathrm{m}(\mathbf{c})$; $300 \mu \mathrm{m}(\mathbf{d}) ; 100 \mu \mathrm{m}(\mathbf{e}, \mathbf{f}) ; 25 \mu \mathrm{m}(\mathbf{g}, \mathbf{h}, \mathbf{i}) ; 20 \mu \mathrm{m}(\mathbf{j})$.

Other materials examined. China. Shanxi Province, Yuanqu County, Lishan Mountain Shunwangping Scenic Area, alt. 2300m, 16 August 2016, in soil under Pinus armandii Franch., K.B. Huang HKB003 (BJTC FAN587); ibid., 16 August 2016, in soil under Pinus armandii Franch., B.D. He HBD014 (BJTC FAN 591); ibid., 17 October 2016, in soil under Pinus armandii Franch., K.B. Huang HKB039 (BJTC FAN689); ibid., 17 October 2016, in soil under Pinus armandii Franch., X.Y. Sang SXY015 (BJTC FAN697); ibid., 17 October 2016, in soil under Pinus armandii Franch., K.B. Huang HKB031 (BJTC FAN714); China. Shanxi Province, Ningwu County, Xiaoshidong Village, Guancen Mountain, alt. 2000m, 12 October 2017, in soil under Picea asperata Mast., L.J. Guo GLJ001 (BJTC FAN1010); China. Gansu Province, Bailongjiang Forestry Bureau, Seventh Forest Farm, alt. 2500m, 14 July 2002, in soil under Pinus sp., D.J. Ren \& M.S. Song 02-034 (HMAS 97115).

Notes. Balsamia lishanensis was diagnosed by the combination of reddish brown ascomata covered with fine warts, the whitish gleba with numerous small chambers open to $1 \mathrm{~mm}, 3-5$ layers peridium reddish brown polygonal cells and the smooth and regular ellipsoid ascospores with one large oil drop. There are four Balsamia spe- 
cies similar to $B$. lishanensis in morphology. Of them, $B$. vulgaris differed by its large ascospores of (23-) 26-32 (-36) × 11.5-14 (-16) $\mu \mathrm{m}$, Balsamia lazyana and B. trappei by their narrow ascospores, which are 19.5-27 $\times 8-11.5 \mu \mathrm{m}$ in B. lazyana and $24-26 \times$ $11.5-13.5 \mu \mathrm{m}$ in B. trappei, B. platyspora by its short-ellipsoid ascospores of 19-22-28 $\times 12-13-16 \mu \mathrm{m}$ (ca. $20 \times 13 \mu \mathrm{m})$. Phylogenetic analysis revealed that the sequences of $B$. lishanensis were grouped into an independent clade with strong support value (Figs $1,2)$. DNA analysis showed that $B$. lishanensis shared less than $87.19 \%$ identity in ITS sequence with other Balsamia species. These supported the erection of the new species.

\section{Balsamia platyspora Berk. Ann. Mag. Nat. Hist.13: 358(1884)}

Figure 4

Materials examined. China. Shanxi Province, Yuanqu County, Lishan Mountain Shunwangping Scenic Area, alt. 2200m, 16 August 2016, in soil under Pinus armandii Franch., Y.W. Wang WYW012 (BJTC FAN557).

Notes. Balsamia platyspora is distributed in Europe, North America and Asia (Berkely 1844; Gilkey 1939). In China, it is reported as early as 1990 from Shanxi Province based on morphological evidences (Liu and Tao 1990), but unfortunately, we have been unable to find the voucher specimen. In this study, our molecular analysis based on 28S sequences (Fig. 1) and ITS sequences (Fig. 2), and morphological studies confirmed the occurrence of this species in China based on the new collections from the Shanxi Province where this species was harvested originally by Liu and Tao (1990). Balsamia platyspora is mainly characterized by its minor subglobose ascomata,

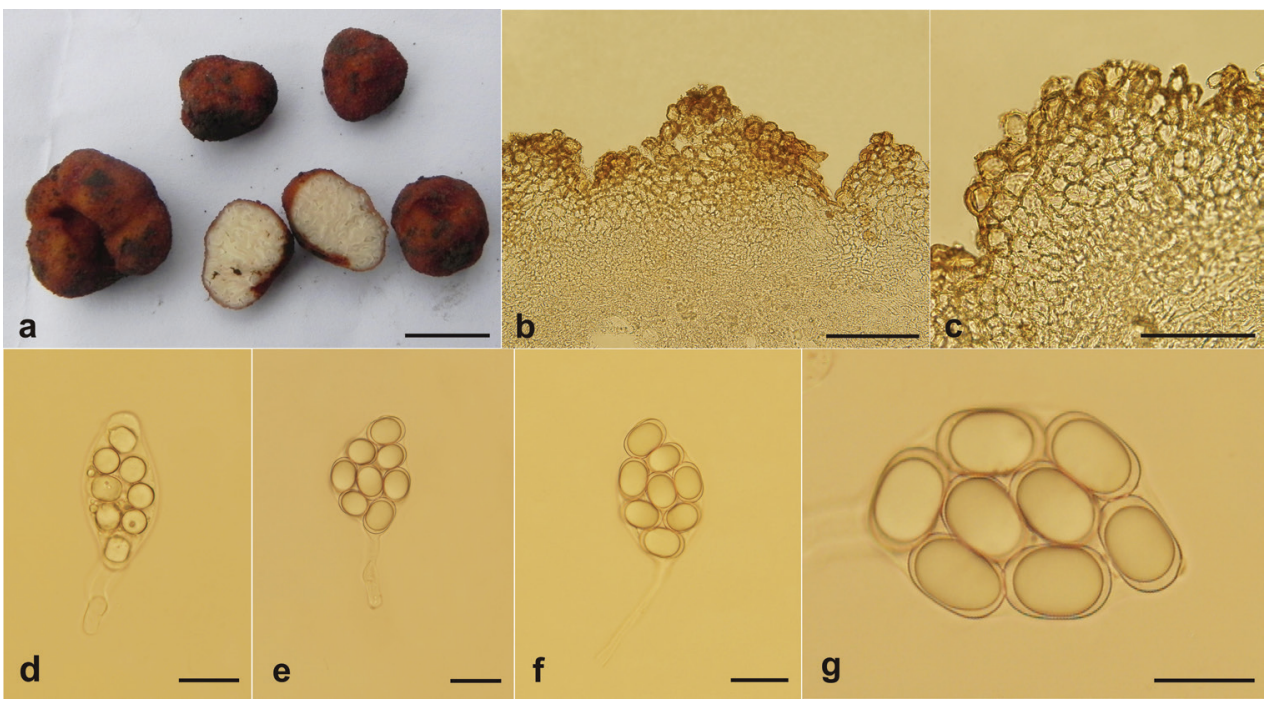

Figure 4. Balsamia platyspora (BJTC FAN557) $\mathbf{a}$ ascomata $\mathbf{b}$ peridium $\mathbf{c}$ warts $\mathbf{d}$ immature ascus $\mathbf{e}, \mathbf{f}$ mature ascus $\mathbf{g}$ ascospores. Scale bars: $1 \mathrm{~cm}(\mathbf{a}) ; 100 \mu \mathrm{m}(\mathbf{b}, \mathbf{c}) ; 25 \mu \mathrm{m}$ (d, e, f); $20 \mu \mathrm{m}(\mathbf{g})$. 
reddish brown to dark brown warts, white to yellowish white gleba with around $1 \mathrm{~mm}$ chambers, citriform or broadly elliptic asci, shortly elliptic ascospores 19-22-28 $\times$ 12-13-16 $\mu \mathrm{m}$ (ca. $20 \times 13 \mu \mathrm{m})$ (Berkeley 1844; Hawker 1954; Pegler et al.1993), our specimen well matched the characteristics.

Balsamia guozigouensis (L. Fan \& Y.Y. Xu) L. Fan \& Y.Y. Xu., comb. nov. MycoBank No: 834963

Basionym. Barssia guozigouensis L. Fan \& Y.Y. Xu, Phytotaxa 374(2): 135 (2018).

Holotype. China. Xinjiang Autonomous Region, Huocheng County, Guozigou Forest Park, alt. 1800m, in soil under Picea schrenkiana Fisch. \& C.A. Mey., 11 August 2003, W.P. Wu \& M. S. Song 060 (HMAS 97107).

Illustrations - Xu et al. (2018: Fig. 4)

Notes. This species is recently described from Xinjiang Autonomous Region, China, under Picea schrenkiana Fisch. \& C.A. Mey. So far it is known only from the type locality. Balsamia guozigouensis can be recognized by its distinctly warty ascomata, solid gleba with small and irregular chamber and irregularly clavate asci. Phylogenetically, it was closely related to B. luyashanensis (Fig. 2), but the latter differs in its ascomata with fine warts and gleba without chambers (Xu et al. 2018).

\section{Balsamia luyashanensis (L. Fan \& Y.Y. Xu) L. Fan \& Y.Y. Xu., comb. nov.} MycoBank No: 834964

Basionym. Barssia luyashanensis L. Fan \& Y.Y. Xu, Phytotaxa 374(2): 134 (2018).

Holotype. China. Shanxi Province, Ningwu County, Qiuqiangou Village, Luyashan Mountain, alt. 2100m, 25 August 2017, in soil under Picea sp., M. Chen CM023 (BJTC FAN764).

Illustrations - Xu et al. (2018: fig. 3)

Notes. Balsamia luyashanensis is also recently described from the Luyashan Mountain of Shanxi Province, China, under Picea sp. So far it is known only from the type locality. The species can be recognized by its red brown ascomata with fine warts, gleba without chambers and irregularly clavate asci (Xu et al. 2018). The species was similar in appearance of ascomata to B. gunerii and B. hellenica but B. gunerii can be separated by its subglobose to ovoid ascospores and gleba with irregularly sinuous, labyrinth-like veins (Doğan et al. 2018; Hansen et al. 2019), while B. hellenica by its ovoid ascospores (Kaounas et al. 2015; Hansen et al. 2019).

\section{Key to Chinese species of Balsamia}

1 Ascomata with an obvious apical depression .................................. 2

- Ascomata without an obvious apical depression .................................... 3 
2 Surface with distinct warts, solid gleba scattered with some small and irregular chambers

B. guozigouensis

- $\quad$ Surface with fine warts, solid gleba without chambers

B. luyashanensis Ascospores long-ellipsoid, $(20.6-25.6 \times 12.9-15 \mu \mathrm{m}, \mathrm{Q}=1.55-1.80)$

B. lishanensis

Ascospores short-ellipsoid, $19-22-28 \times 12-13-16 \mu \mathrm{m}$ (ca. $20 \times 13 \mu \mathrm{m})$ (Hawker 1954).

B. platyspora

\section{Acknowledgements}

Dr. J.Z. Cao was appreciated for collecting specimens and providing valuable suggestions. The study was supported by the National Natural Science Foundation of China (No. 31750001) and the Beijing Natural Science Foundation (No. 5172003).

\section{References}

Alfaro ME, Zoller S, Lutzoni F (2003) Bayes or bootstrap? A simulation study comparing the performance of Bayesian Markov chain Monte Carlo sampling and bootstrapping in assessing phylogenetic confidence. Molecular Biology and Evolution 20(2): 255-266. https:// doi.org $/ 10.1093 / \mathrm{molbev} / \mathrm{msg} 028$

Alvarado P, Moreno G, Manjón JL, Gelpi C, Kaounas V, Konstantinidis G, Barseghyan GS, Venturella G (2011) First molecular data on Delastria rosea, Fischerula macrospora and Hydnocystis piligera. Boletín de la Sociedad Micológica de Madrid 35: 31-37.

Ariyawansa HA, Hyde KD, Jayasiri SC, Buyck B, Chethana KWT, Dai DQ, Dai YC, Daranagama DA, Jayawardena RS, Lücking R, Ghobad-Nejhad M, Niskanen T, Thambugala KM, Voigt K, Zhao RL, Li G-J, Doilom M, Boonmee S, Yang ZL, Cai Q, Cui Y-Y, Bahkali AH, Chen J, Cui BK, Chen JJ, Dayarathne MC, Dissanayake AJ, Ekanayaka AH, Hashimoto A, Hongsanan S, Jones EBG, Larsson E, Li WJ, Li Q-R, Liu JK, Luo ZL, Maharachchikumbura SSN, Mapook A, McKenzie EHC, Norphanphoun C, Konta S, Pang KL, Perera RH, Phookamsak R, Phukhamsakda C, Pinruan U, Randrianjohany E, Singtripop C, Tanaka K, Tian CM, Tibpromma S, Abdel-Wahab MA, Wanasinghe DN, Wijayawardene NN, Zhang J-F, Zhang H, Abdel-Aziz FA, Wedin M, Westberg M, Ammirati JF, Bulgakov TS, Lima DX, Callaghan TM, Callac P, Chang C-H, Coca LF, Dal-Forno M, Dollhofer V, Fliegerová K, Greiner K, Griffith GW, Ho H-M, Hofstetter V, Jeewon R, Kang JC, Wen T-C, Kirk PM, Kytövuori I, Lawrey JD, Xing J, Li H, Liu ZY, Liu XZ, Liimatainen K, Lumbsch HT, Matsumura M, Moncada B, Nuankaew S, Parnmen S, de Azevedo Santiago ALCM, Sommai S, Song Y, de Souza CAF, de Souza-Motta CM, Su HY, Suetrong S, Wang Y, Wei S-F, Wen TC, Yuan HS, Zhou LW, Réblová M, Fournier J, Camporesi E, Luangsa-ard JJ, Tasanathai K, Khonsanit A, Thanakitpipattana D, Somrithipol S, Diederich P, Millanes AM, Common RS, Stadler M, Yan JY, Li XH, Lee HW, Nguyen TTT, Lee HB, Battistin E, Marsico O, Vizzini A, Vila J, Ercole E, Eberhardt U, Simonini G, Wen H-A, Chen X-H, Miettinen O, Spirin V, Hernawati (2015) Fungal diversity notes 111-252- 
taxonomic and phylogenetic contributions to fungal taxa. Fungal Diversity 75(1): 27-274. https://doi.org/10.1007/s13225-015-0346-5

Benucci GMN, Raggi L, Albertini E, Csorbai AG, Donnini D (2014) Assessment of ectomycorrhizal biodiversity in Tuber macrosporum productive sites. Mycorrhiza 24(4): 281-292. https://doi.org/10.1007/s00572-013-0538-3

Berkeley MJ (1844) Notices of British Fungi. Journal of Natural History. 13(85): 340-360. https://doi.org/10.1080/03745484409442617

Bidartondo MI, Read DJ (2008) Fungal specificity bottlenecks during orchid germination and development. Molecular Ecology 17(16): 3707-3716. https://doi.org/10.1111/j.1365294X.2008.03848.x

Bonito G, Trappe JM, Rawlinson P, Vilgalys R (2010) Improved resolution of major clades within Tuber and taxonomy of species within the Tuber gibbosum complex. Mycologia 102(5): 1042-1057. https://doi.org/10.3852/09-213

Bonito G, Smith ME, Nowak M, Healy RA, Guevara G, Cazares E, Kinoshita A, Nouhra ER, Dominguez LS, Tedersoo L, Murat C, Wang Y, Moreno BA, Pfister DH, Nara K, Zambonelli A, Trappe JM, Vilgalys R (2013) Historical biogeography and diversification of truffles in the Tuberaceae and their newly identified southern hemisphere sister lineage. PLoS One 8(1): e52765. https://doi.org/10.1371/journal.pone.0052765

Crous PW, Wingfield MJ, Schumacher RK, Summerell BA, Giraldo A, Gené J, Guarro J, Wanasinghe DN, Hyde KD, Camporesi E, Gareth Jones EB, Thambugala KM, Malysheva EF, Malysheva VF, Acharya K, Álvarez J, Alvarado P, Assefa A, Barnes CW, Bartlett JS, Blanchette RA, Burgess TI, Carlavilla JR, Coetzee MPA, Damm U, Decock CA, den Breeÿen A, de Vries B, Dutta AK, Holdom DG, Rooney-Latham S, Manjón JL, Marincowitz S, Mirabolfathy M, Moreno G, Nakashima C, Papizadeh M, Shahzadeh Fazeli SA, Amoozegar MA, Romberg MK, Shivas RG, Stalpers JA, Stielow B, Stukely MJC, Swart WJ, Tan YP, van der Bank M, Wood AR, Zhang Y, Groenewald JZ (2014) Fungal Planet description sheets: 281-319. Persoonia 33: 212-289. https://doi.org/10.3767/003158514X685680

Doğan HH, Bozok F, Taşkın H (2018) A new species of Barssia (Ascomycota, Helvellaceae) from Turkey. Turkish Journal of Botany 42: 1-8. https://doi.org/10.3906/bot-1801-33

Dring DM (1971) Techniques for microscopic preparation. In: Booth C (Ed.) Methods in microbiology, vol 4. Academic, New York, 98 pp. https://doi.org/10.1016/S0580-9517(09)70008-X

Gardes M, Bruns TD (1993) ITS primers with enhanced specificity for basidiomycetes - application to the identification of mycorrhizae and rusts. Molecular Ecology 2(2): 113-118. https://doi.org/10.1111/j.1365-294X.1993.tb00005.x

Gilkey HM (1939) Tuberales of North America. Oregon State Monographs. Studies in Botany 1: $1-63$.

Hansen K, Schumacher T, Skrede I, Huhtinen S, Wang XH (2019) Pindara revisited-evolution and generic limits in Helvellaceae. Persoonia 42: 186-204. https://doi.org/10.3767/ persoonia.2019.42.07

Hawker LE (1954) British hypogeous fungi. Philosophical Transactions of the Royal Society of London. Series B, Biological Sciences 237: 429-546. https://doi.org/10.1098/ rstb.1954.0002 
Hillis DM, Bull JJ (1993) An empirical test of bootstrapping as a method for assessing confidence in phylogenetic analysis. Systematic Biology 42(2): 182-192.

Izzo AD, Meyer M, Trappe JM, North M, Bruns TD (2005) Hypogeous ectomycorrhizal fungal species on roots and in small mammal diet in a mixed-conifer forest. Forest Science 51(3): 243-254. https://doi.org/10.1093/sysbio/42.2.182

Kaounas V, Agnello C, Alvarado P, Slavova M (2015) Barssia hellenica sp. nov. (Ascomycota, Pezizales), a new hypogeous species from Greece. Ascomycete.org 7(5): 213-219.

Katoh K, Standley DM (2013) MAFFT multiple sequence alignment software version 7: improvements in performance and usability. Molecular Biology and Evolution 30: 772-780. https://doi.org/10.1093/molbev/mst010

Ławrynowicz M, Skirgiełło A (1984) Barssia oregonensis found in the Tatra Mountains (Poland). Acta Mycologica 20(2): 277-280. https://doi.org/10.5586/am.1984.023

Liu B, Tao K (1990) New species and new records of hypogeous fungi from China III. Acta Mycologica Sinica 9(1): 25-30.

Nguyen NH, Landeros F, Garibay-Orijel R, Hansen K, Vellinga EC (2013) The Helvella lacunosa species complex in western North America: cryptic species, misapplied names and parasites. Mycologia 105(5): 1275-1286. https://doi.org/10.3852/12-391

Nylander J (2004) MrModeltest 2.2. Computer software distributed by the Evolutionary Biology Centre, University of Uppsala, Uppsala.

O’Donnell K, Cigelnik E, Weber NS, Trappe JM (1997) Phylogenetic relationships among ascomycetous truffles and the true and false morels inferred from $18 \mathrm{~S}$ and $28 \mathrm{~S}$ ribosomal DNA sequence analysis. Mycologia 89(1): 48-65. https://doi.org/10.1080/00275514.19 97.12026754

Page RD (2001) TreeView. Glasgow University, Glasgow.

Pegler DN, Spooner BM, Young TWK (1993) British truffles: A Revision of British Hypogeous Fungi. Kew Royal Botanic Gardens, 56-61.

Petitberghien A (1966) Note sur deux champignons hypogés. Bulletin trimestrial de la Société mycologique de France 82: 460-465.

Rambaut A (2000) Estimating the rate of molecular evolution: incorporating non-contemporaneous sequences into maximum likelihood phylogenies. Bioinformatics 16: 395-399. https://doi.org/10.1093/bioinformatics/16.4.395

Ronquist F, Huelsenbeck JP (2003) MrBayes 3: Bayesian phylogenetic inference under mixed models. Bioinformatics 19(12): 1572-1574. https://doi.org/10.1093/bioinformatics/btg180

Roy M, Rochet J, Manzi S, Jargeat P, Gryta H, Moreau PA, Gardes M (2013) What determines Alnus-associated ectomycorrhizal community diversity and specificity? A comparison of host an habitat effects at a regional scale. New Phytologist 198 (4): 1228-1238. https:// doi.org/10.1111/nph.12212

Schulzer S (1870) Mykologische Beobachtungen aus Nord-Ungarn im Herbste 1869. Verhandlungen der Zoologisch-Botanischen Gesellschaft Wien 20: 169-210.

Skrede I, Carlsen T, Schumacher T (2017) A synopsis of the saddle fungi (Helvella: Ascomycota) in Europe-species delimitation, taxonomy and typification. Persoonia 39: 201-253. https://doi.org/10.3767/persoonia.2017.39.09 
Southworth D, Frank JL, Castellano MA, Smith ME, Trappe JM (2018) Balsamia (Sequestrate Helvellaceae, Ascomycota) in western North America. Fungal Systematics and Evolution 2: 11-36. https://doi.org/10.3114/fuse.2018.02.02

Stamatakis A (2014) RAxML version 8: a tool for phylogenetic analysis and post-analysis of large phylogenies. Bioinformatics 30(9): 1312-1313. https://doi.org/10.1093/bioinformatics/btu033

Swofford DL (2002) PAUP*: Phylogenetic analysis using parsimony (and Other Methods). Version 4.0b10. Sinauer Associates. Sunderland.

Timling I, Dahlberg A, Walker DA, Gardes M, Charcosset JY, Welker JM, Taylor DL (2012) Distribution and drivers of ectomycorrhizal fungal communities across the North American Arctic. Ecosphere 3(11): 1-25. https://doi.org/10.1890/ES12-00217.1

Tulasne LR, Tulasne C (1843) Champignons hypogés de la famille des Lycoperdacées, observés dans les environs de Paris et les départements de la Vienne et d'Indre-et-Loire. Annales des Sciences Naturelles Série 2(19): 373-381.

Tulasne LR, Tulasne C (1851) Fungi Hypogæi. Histoire et Monographie des Champignon Hypogés. Apud Friedrich Klincksieck, Paris, 123-125.

Vilgalys R, Hester M (1990) Rapid genetic identification and mapping of enzymatically amplified ribosomal DNA from several Cryptococcus species. Journal of Bacteriology 172(8): 4239-4246. https://doi.org/10.1128/JB.172.8.4238-4246.1990

Vittadini C (1831) Monographia Tuberacearum. Mediolani, 1-88.

White TJ, Bruns T, Lee S, Taylor J (1990) Amplification and direct sequencing of fungal ribosomal RNA genes for phylogenetics. In: Innis MA, Gelfand DH, Sninsky JJ, White TJ (Eds) PCR protocols: a guide to methods and applications. Academic Press, New York, 315-322. https://doi.org/10.1016/B978-0-12-372180-8.50042-1

Xu YY, Guo LJ, Li T, Fan L (2018) Two new species of Barssia from China. Phytotaxa 374(2): 129-138. https://doi.org/10.11646/phytotaxa.374.2.4

Zhao Q, Brooks S, Zhao YC, Yang ZL, Hyde KD (2016) Morphology and phylogenic position of Wynnella subalpina sp. nov. (Helvellaceae) from western China. Phytotaxa 270(1): 41-48. https://doi.org/10.11646/phytotaxa.270.1.4

\section{Supplementary material I}

Table S1. Taxa used in this study and their GenBank accession numbers for ITS and $28 S$ sequence data

Authors: Yu-Yan Xu, Xiang-Yuan Yan, Ting Li, Li Fan

Data type: Microsoft Word Document (.docx)

Copyright notice: This dataset is made available under the Open Database License (http://opendatacommons.org/licenses/odbl/1.0/). The Open Database License $(\mathrm{ODbL})$ is a license agreement intended to allow users to freely share, modify, and use this Dataset while maintaining this same freedom for others, provided that the original source and author(s) are credited.

Link: https://doi.org/10.3897/mycokeys.67.50068.suppl1 